\title{
Performance of Brewery Digestate as a Potential Water Substitute in Concrete Applications
}

ISSN: 2576-8840

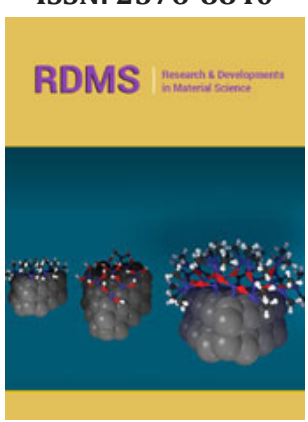

*Corresponding author: Ahmed A, School of the Built Environment and Engineering, Leeds Beckett University, United Kingdom

Submission: 械 September 03, 2020

Published:

Volume 14 - Issue 1

How to cite this article: Ahmed A, Hurst G, Peeters M and Tedesco S. Performance of Brewery Digestate as a Potential Water Substitute in Concrete Applications. Res Dev Material Sci. 14(1). RDMS.000830. 2020. DOI: 10.31031/RDMS.2020.14.000830

Copyright@ Ahmed A. This article is distributed under the terms of the Creative Commons Attribution 4.0 International License, which permits unrestricted use and redistribution provided that the original author and source are credited.

\author{
Ahmed $\mathrm{A}^{1 *}$, Hurst $\mathrm{G}^{2}$, Peeters $\mathrm{M}^{3}$ and Tedesco $\mathrm{S}^{2}$ \\ ${ }^{1}$ School of the Built Environment and Engineering, Leeds Beckett University, United Kingdom \\ ${ }^{2}$ Department of Mechanical Engineering, Manchester Metropolitan University, United \\ Kingdom \\ ${ }^{3}$ School of Engineering, Newcastle University, United Kingdom.
}

\begin{abstract}
Concrete is one of the most utilised materials in the world. It is used to construct buildings, bridges and highways and is comprised of four key ingredients: cement, sand, gravel, and water. Although, there are environmental implications regarding the use of concrete, e.g. high embodied CO2, it is a flexible material in that it is possible to incorporate waste materials whilst maintaining structural integrity. Very little work has been done in replacing or partially substituting water as the hydration of cement is a key reaction to strength development. This paper investigates the possibility of utilising wastewater sludge (WWS) from the brewery industry as a water substitute in concrete. With the adverse effects of climate change resulting in water shortages around the world, there are sustainable implications of finding water substitutes. Experiments were carried out by supplementing water by volume in concrete mixes with WWS at 25\%, 50\%, and 100\% steps at the point of need. Results were compared with a control specimen, which was made with $100 \%$ pure water. The results showed impressive compressive strengths that were suitable for structural applications, even at $100 \%$ WWS content. The results showed good repeatability and highlight the potential of WWS as a water replacement, which could enhance the sustainability aspect of concrete.
\end{abstract}

\section{Introduction}

There is potential to use wastewater sludge as a partial water replacement in concrete. Concrete is made from four basic ingredients: cement (binder), sand (fine aggregates), gravel (coarse aggregates) and water. It is a predominant material used in construction worldwide and widely used in all types of civil engineering works, including infrastructure, buildings, housing, hospitals, and environment protection [1-4]. Proportions of each ingredient/ constituents are adjusted to produce a well-balanced concrete. It is a versatile material with important properties such as strength, durability, versatility, affordability, fire-resistance, and thermal mass. Furthermore, it is locally produced and utilised in all countries. Although, there are sustainability issues with concrete especially the high embodied $\mathrm{CO}_{2}$, it is a flexible material whereby it is possible to replace the fine aggregates, coarse aggregates, and binder with other recycled or waste materials [4]. So far, there has been little research done on replacing the water which is an important constituent of concrete with most mixes containing approximately 180 litres per $\mathrm{m}^{3}$ of concrete. It is vitally important water is present to hydrate the cement otherwise this will adversely affect the mechanical properties.

When cement is mixed with water it reacts and its constituent compounds undergo a series of chemical reactions that are responsible for hardening of the concrete [2]. This process is called the hydration of cement [3]. Cement usually comprises of four compounds: dicalcium silicate, tricalcium silicate, tricalcium aluminate and tetracalcium aluminoferrite. Specifically, water reacts with tricalcium silicate and dicalcium silicate, the most reactive compounds in cement. During this first reaction cement, the calcium silicates react chemically with water to produce a hard paste-gel (that coats the aggregates) made up of calcium silicate hydrates (CSH) phase which is the major contributor to strength in concrete [1-9]. 


\section{The first reaction involves tricalcium silicate:}

Tricalcium Silicate + Water ---> Calcium Silicate Hydrate + Calcium Hydroxide (lime) + Heat (reaction 1)

The initial reaction also involves dicalcium silicate:

Dicalcium Silicate + Water --->Calcium Silicate Hydrate+Calcium Hydroxide (lime) + Heat (reaction 2)

A recent estimate [10] indicates that 380 billion $\mathrm{m}^{3}$ of wastewater is produced on an annual basis, which is expected to rise by nearly $50 \%$ by 2050 . This water contains a substantial amount of nutrients, including a reported 16.6. Tg of nitrogen, which has potential to be used in agriculture or provide electricity.

In the brewing industry, the average water consumption is estimated at $\sim 5 \mathrm{~L} / \mathrm{L}$ beer [11]. Common brewery by-products are spent grain, spent yeast, and spent hops/hot trub in high volume (16.9 million tons/year of spend grain, 250 thousand tons/year of hot trub, 2.1 million tons/year brewery residual waste [12]), which create a valuable opportunity for utilising waste streams to optimise environmental and economic sustainability. There are several funding schemes available in the UK, especially targeted towards small scale companies including microbreweries, which are interesting opportunities to save on electricity costs while creating additional income. A 2010 study [13] collected data from 156 breweries, representing $62 \%$ of the total beer production volume in European countries, to demonstrate the commitment of the brewing industry to sustainability. Anaerobic digestion (AD) is a typical technology adopted to valorise these brewery waste to bioenergy via production of a renewable gaseous energy carrier (biogas) and a liquid slurry by-product (digestate). The Renewable Heat Incentive that was introduced in 2011 offers up to $200 \mathrm{~kW}$ rate at a rate of $0.065 £ / \mathrm{kWh}$ for equipment running on biogas or biofuel.

Digestate is the main by-product of the AD technology [14], usually employed as fertiliser. This allows to recycle nutrients and reduces the use of mineral fertiliser in agronomic plant production, which improves the sustainability of biogas production. However, land spreading is subjected to local environmental regulations [15] and it has been found to contribute to GHG gas emissions [16]. Furthermore, since the main criteria for digestion is energy production, residence time of the biowaste in the reactor can be limited [17], which can lead to digestate still containing traces of organic compounds that are normally easily-degraded. Thus, the use of digestate in land fertiliser is questioned due to issues around toxicity and leaching of micropollutants, such as endocrine disruptors [18], into the environment. An unexplored alternative to land spreading of digestate is its use in the construction sector as replacement for water in concrete (as dry matter content is $<10 \%$ d.w.), due to the carbon sequestration potential of this process to lock organic carbon into the concrete, preventing its release into the environment by combustion-like technologies or land spreading.

As digestate wastewaters are made up predominantly by water, theoretically, the hydration of cement should take place leading to the formation of the CSH phase. Therefore, there is potential to use brewery digestate at least as a partial water replacement in concrete. This paper investigates the feasibility of replacing water in concrete with brewery digestate and how its composition and other properties affect strength. Alternative use for further biogas production and land spreading are also discussed.

\section{Materials and Methods}

\section{Brewery sludge characterisation methods}

Samples of brewery sludge were collected in mid-September 2019 from a local brewery in Greater Manchester, United Kingdom. These were spilled from a secondary anaerobic digester used to produce biogas on site for heat and electricity generation purposes. The samples underwent proximate analysis straight away after collection and were dried, after weighting, in a muffle furnace at $105{ }^{\circ} \mathrm{C}$ overnight, followed by combustion at $575^{\circ} \mathrm{C}$, as by standard procedure [19] to derive the moisture, total solids (TS) and volatile solid (VS) weight splits in percentage. The proximate and elemental characterisation were conducted in triple replication, and CHNS-O weights (\%) were detected using an Elemental Vario MacroCube analyser (Elementar, Germany), with \%O calculated by difference, see equation (1).

Oxygen $(\%)=100$-Carbon (\% Dry Basis)-Hydrogen (\% Dry Basis)-Nitrogen (\% Dry Basis)-Sulphur (\% Dry Basis)-Ash(\% Dry Basis) equation(1)

Prior to use as water replacement in the concrete mixes, the sludge was left to degasify in an anaerobic environment $(500 \mathrm{~mL}$ bioreactors) until the biogas volume produced was $<1 \%$ of the cumulative volume, as per standard protocol (VDI 4630 [20]). The biogas produced was collected in sealed bags and subsequently analysed for composition using a GeoTech 2000 biogas analyser at the end of the digestion period. The major water-soluble ions in the digestate were determined using an ion-chromatography system equipped with a conductivity detector (ICS5000, Thermo Scientific, USA).

\section{Concrete mix preparation and testing}

The wastewater described above was used to prepare the concrete mixes used in this investigation. The mixes details are shown in Table 1, the cement used was type CEM $152.5 \mathrm{~N}$ conforming to BS EN 197-1: 2000 [21]. Cube moulds that were used to make specimens measured $100 \mathrm{~mm} \times 100 \mathrm{~mm} \times 100 \mathrm{~mm}$ conforming to European codes, BS EN 12390-1:2012 [22] and the specimens were cast conforming to BS EN 12390-2:2009 [23]. The target mix of the study was strength class $\mathrm{C} 32 / 40$ at approximate mix proportions of 1: 2: 3 (cement: sand: gravel). The water content was substituted with wastewater sludge in percentages of $0 \%, 25 \%, 50 \%$, and $100 \%$. The $0 \%$ replacement also referred to as the 'control specimen' was used as the reference to which the performance of all replacements was measured. A constant water cement ratio (WCR) of 0.5 was used for all mixes for a good balance of workability and strength in line with Abram's law which states that the strength of a concrete mix is determined by the WCR, with 
lower WCR spelling higher strengths and vice-versa [24,25]. To ensure repeatability, a total of three cubes were cast for each testing age and the characteristic compressive strength was reported [6]. The cubes were left in the moulds for 24 hours, before being stripped, marked, and submerged in a water tank at temperatures of $20^{\circ} \mathrm{C} \pm 2$ until their testing age. Compressive tests conformed to BS EN 12390-4:2000 [26,27] at 7 and 28 days.

Table 1: Experimental set up of concrete mixes preparation.

\begin{tabular}{|c|c|c|c|c|c|}
\hline MIX & $\begin{array}{c}\text { Cement } \\
\text { (kg) }\end{array}$ & $\begin{array}{c}\text { Fine } \\
\text { Aggregate } \\
\text { (kg) }\end{array}$ & $\begin{array}{c}\text { Coarse } \\
\text { Aggregate } \\
\text { (kg) }\end{array}$ & $\begin{array}{c}\text { Water } \\
\text { (litres) }\end{array}$ & $\begin{array}{c}\text { Wet } \\
\text { Sludge } \\
\text { (litres) }\end{array}$ \\
\hline $\begin{array}{c}\text { Control } \\
\text { WS1 }\end{array}$ & 3.6 & 6.1 & 11.4 & 1.8 & 0 \\
\hline $\begin{array}{c}\text { WS2 } \\
(25 \%)\end{array}$ & 3.6 & 6.1 & 11.4 & 1.35 & 0.45 \\
\hline $\begin{array}{c}\text { WS3 } \\
(50 \%)\end{array}$ & 3.6 & 6.1 & 11.4 & 0.9 & 0.9 \\
\hline $\begin{array}{c}\text { WS4 } \\
(100 \%)\end{array}$ & 3.6 & 6.1 & 11.4 & 0 & 1.8 \\
\hline
\end{tabular}

\section{Results \& Discussion}

\section{Physiochemical composition for bioenergy and land} spreading

Table 2: Brewery sludge characterisation.

\begin{tabular}{|c|c|}
\hline \multicolumn{2}{|c|}{ Proximate Analysis (Wet Basis) } \\
\hline $\mathrm{pH}$ & 7.5 \\
\hline Total Solids Content (wt\%) & 9.8 \\
\hline VS content (wt\%) & 7.2 \\
\hline Ash (wt\%) & 2.6 \\
\hline \multicolumn{2}{|c|}{ Elemental Analysis (wt.\% Dry Basis) } \\
\hline $\mathrm{C}$ & 40.3 \\
\hline $\mathrm{H}$ & 6 \\
\hline $\mathrm{N}$ & 9.1 \\
\hline $\mathrm{S}$ & 0.8 \\
\hline 0 & 17.6 \\
\hline Ash & 26.2 \\
\hline \multicolumn{2}{|c|}{ Major Water-Soluble Ions (g/L) } \\
\hline Ammonium & 0.9361 \\
\hline Nitrate & 0.0909 \\
\hline Phosphate & 0.016 \\
\hline Sodium & 2.109 \\
\hline Chloride & 0.3025 \\
\hline Potassium & 1.9117 \\
\hline Magnesium & $<0.002$ \\
\hline Calcium & 0.018 \\
\hline
\end{tabular}

Results from the proximate, elemental, and major ion analysis are reported in Table 2, all measurements had standard deviations $<1 \%$. These will be discussed in detail in the following sub-sections in relation to further (secondary) biogas production and land fertilization.

Suitability for further bioenergy production: The $\mathrm{pH}$ of the brewery samples was measured at approximately 7.5. This slightly alkaline value was expected, since $\mathrm{AD}$ bacterial consortia operate within the 7.5-8.5 range of $\mathrm{pH}$ [28]. Proximate analysis results clearly show this substrate has a very high moisture content ( $\sim 90 \%$ w./w.) which indicates its suitability for concrete applications as water replacement. The organics presence, in volatile solids (VS), shows that about $7.2 \%$ (w./w). is degradable matter, with values mostly in line with other brewery digestate [29]. At the end of the digestion period ( $~ 28$ days), the degradation resulted in the production of biogas, with an average methane yield of $44.0 \mathrm{CH}_{4} \mathrm{~mL} / \mathrm{g}_{\mathrm{vs}}$. This value is very low compared to the theoretical methane potential that can be produced from the brewery effluent, that is 576.8 $\mathrm{CH}_{4} \mathrm{ml} / \mathrm{g}_{\mathrm{vs}}$ (calculated by well-known Buswell equation, [30]). Such difference indicates the biological degradation rate of the substrate is very low, as also reported in a similar study [31], not making the substrate ideal for bioenergy production but its compositional characteristics could instead accommodate organics incarceration into concrete over landfill disposal, with obvious environmental benefits. Carbon is captured in the form of carbon dioxide, hence carbon can be sequestrated via the barley plant life cycle, when the crop is grown by the brewery industry and it will still be present $(40.30 \% \mathrm{C})$ in the brewery effluents in large quantities. This is quite important as cement has a very large, embodied $\mathrm{CO}_{2}$; approximately one tonne is emitted to produce one tonne of cement $[1,27]$.

Results from the biogas composition analysis also revealed the presence of gaseous ammonia (452ppm) and hydrogen sulphide $(514 \mathrm{ppm})$, which are common minor by-products of anaerobic digestion as result of the action of nitrate and sulphate reducing bacteria. Previous work on bacterial identification in these wastewater samples confirmed the presence of these bacteria [32]. The presence of corrosive and poisonous gases at the detected concentration, will normally imply purification of the biogas is conducted prior to combustion in co-generation units to preserve the life in service of the system. Biogas upgrading adds up to the operational costs of an AD plant and the low methane production rate found in this study would not justify this option in economic gains, unless more nutrients are supplied to the bioreactors to increase the volume of methane generated that can be burnt (approximately $10.3 \mathrm{kWh}$ per $\mathrm{m}^{3}$ of methane). Although chloride ions are present in the sludge, these are very minimal at $0.3 \mathrm{~g} / \mathrm{L}$. On the assumption of a concrete mix containing $100 \%$ sludge as a replacement for water and an average cement content of $350 \mathrm{~kg} / \mathrm{m}^{3}$ with a general water/cement ratio of 0.5 represents a $0.00015 \%$ chloride content by mass of cement. This is over 2500 times below the low corrosion risk level for reinforced concrete. 
Suitability for land spreading and landfill disposal: The spreading of organic fertilizers generally has a positive effect on soil chemical properties [33]; the digestate is rich in ammonia which is directly available to plants and would therefore improve soil quality. However, there are concerns around the traces of heavy metals, organic pollutants and antibiotic residues that will accumulate in the food chain [33]. Brewery water is known to be full of organic pollutants, which increases the concern of this waste as fertilizer [34].

Furthermore, land application of digestate as a fertiliser has led to eutrophication of marine environments [35], due to nitrate and phosphate rain runoff. However, the brewery digestate has relatively little nitrate and phosphate. Biochar derived from a variety of feedstock thermochemical conversion technologies appears to be more environmentally friendly soil amenders than digestate [36], in terms of both carbon sequestration potential, limited toxics leaching and stimulating growth of microbial community into the soil.

\section{Suitability and performance for concrete applications}

Workability: The workability of concrete is a very important property. Before the concrete has set and hardened, workability is one of the most important properties of fresh concrete; it is defined as the ability of concrete to flow, be compacted, and perform sufficiently in transporting processes [37]. Workability is the property of freshly mixed concrete which determines the ease and homogeneity with which it can be mixed, placed, consolidated, and finished [27,38]. Workability can also be defined as the property determining the effort required to manipulate a freshly mixed quantity of concrete with minimum loss of homogeneity. Workability of concrete depends on many factors and is directly proportional to water to cement ratio. An increase in water to cement ratio increases the workability. Generally, a water cement ratio of 0.45 to 0.6 is used for good workable concrete without the use of any admixtures or plasticisers. The higher water/cement ratio, higher will be the water content per volume of concrete and the concrete will be more workable. Higher water/cement ratio is generally used for manual concrete mixing to make the mixing process easier; however, this needs to be balanced with strength requirement as the compressive strength is adversely proportional to the water/cement ratio as per Abram's Law [27].

Workability of concrete is measured in terms of ease with which it can be mixed, transported to construction site, placed in forms, and compacted. Other factors affecting the workability besides water to cement ratio are materials such as cement content, sand, and aggregate properties such as size, shape, grading, mix design and admixtures [39]. There are many types of admixtures used in concrete for enhancing its properties. There are some workability enhancer admixtures such as plasticizers and superplasticizers which increases the workability of concrete even with low water/ cement ratio. They are also called water reducing agents as they reduce the quantity of water required for same value of slump [7,37-39].

Table 3 shows the slumps of wastewater sludge replaced mixes at different replacement levels. The table also indicates if the mix was coherent and whether the addition of a plasticiser (water reducing agent) was required.

Table 3: Compressive strength of wastewater sludge replaced mixes (MPa).

\begin{tabular}{|c|c|c|c|c|}
\hline Specimen & WS1 Control (0\%) & WS2 (25\%) & WS3 (50\%) & $\begin{array}{c}\text { WS4 } \\
(\mathbf{1 0 0 \% )}\end{array}$ \\
\hline Slump (mm) & 70 & 60 & 30 & No slump \\
\hline Plasticiser Required & No & No & No & Yes \\
\hline Coherent Mix & Yes & Yes & Yes & Yes \\
(with plasticiser)
\end{tabular}

Workability was observed to decrease with increased replacement; this can possibly be attributed to increase in solid content which is present in the sludge solution. With $100 \%$ sludge there was no slump however a minimal dosage of plasticiser resulted in a workable and coherent mix. This a key finding for potential future use of wastewater sludge that even with $100 \%$ replacement it is still possible to achieve a coherent and workable mix.

Table 4: Characteristic compressive strengths (fck) of wastewater sludge replaced concrete mixes (MPa).

\begin{tabular}{|c|c|c|c|c|}
\hline Curing Age (days) & $\begin{array}{c}\text { WS1 } \\
\text { Control (0\%) }\end{array}$ & $\begin{array}{l}\text { WS2 } \\
(25 \%)\end{array}$ & $\begin{array}{l}\text { WS3 } \\
(50 \%)\end{array}$ & $\begin{array}{c}\text { WS4 } \\
(100 \%)\end{array}$ \\
\hline 7 & 38 & 38 & 33 & 33 \\
\hline 28 & 46 & 48 & 40 & 35 \\
\hline C32/40 classification met & Y & Y & Y & $\mathrm{N}$ \\
\hline $\begin{array}{l}\text { Actual Strength } \\
\text { Classification }\end{array}$ & $\mathrm{C} 35 / 45$ & C35/45 & $\mathrm{C} 32 / 40$ & $\mathrm{C} 28 / 35$ \\
\hline
\end{tabular}


Compressive strength: Table 4 and Figure 1 show the characteristic compressive strengths at 7 and 28 days of hardened concrete with $0 \%, 25 \%, 50 \%$, and $100 \%$ wastewater sludge replacement. The compressive strength of any material is defined as the resistance to failure under the action of compressive forces. Especially for concrete, compressive strength is an important parameter to determine the performance of the material during service conditions. The characteristic strength (fck) is defined as the strength of the concrete below which not more than $5 \%$ of the test results are expected to fall. The fck is determined as specified in the British and European standards [26,27].

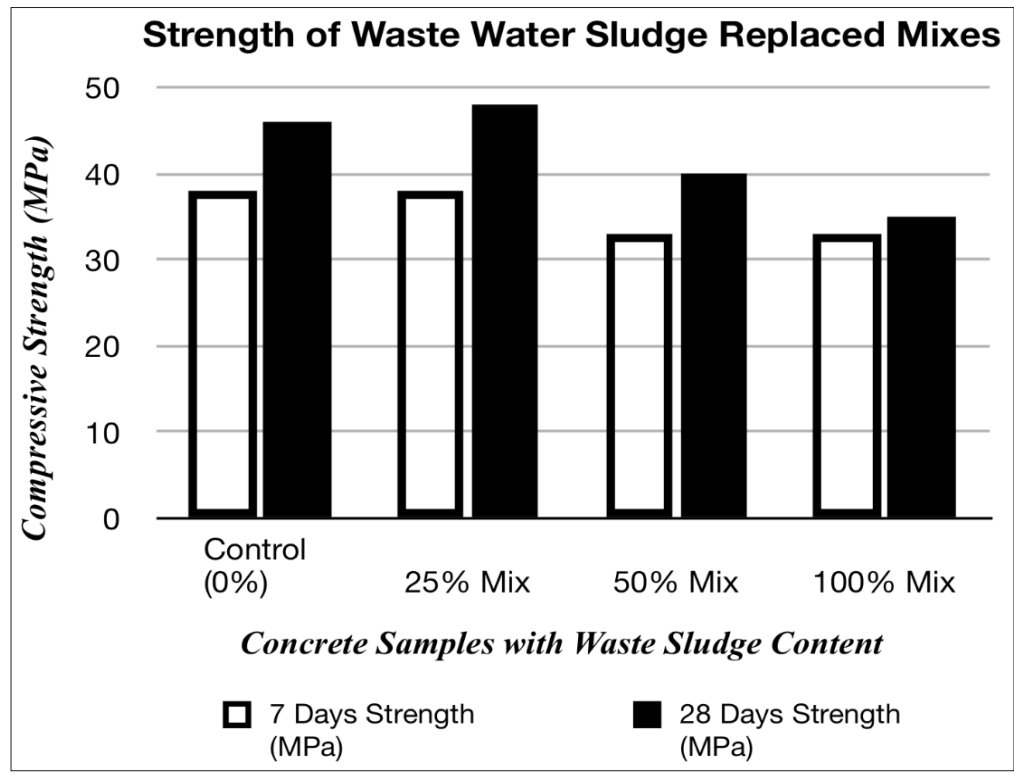

Figure 1: Characteristic compressive strength trend of wastewater sludge concrete mixes.

The results show that sample WS2 with 25\% sludge content had a marginally higher strength than the control mix. It is also worth noting all the waste sludge concrete mixes exhibited excellent early age strengths of over $30 \mathrm{MPa}$ within 7 days. This is very important especially in the construction of multi-storey buildings, therefore, increasing the efficiency on site with minimal delays.

The target strength design mix was C32/40. All the mixes up to $50 \%$ waste sludge content achieved strengths that satisfied the targeted class C32/40 at 28 days, which is among strength classes listed by BS EN 1992-1-1: 2004 [40] and BS 8500-1:2015 [41], as being suitable for structural applications. However, all replacements showed impressive strengths including WS4 (100\% sludge content), which satisfies the C28/35 strength classification. With characteristic compressive strengths between $35-45 \mathrm{MPa}$, the mixes can be utilised for many types of structural applications, e.g. municipal buildings, flooring applications in dwellings, foundations, and bridges. Furthermore, by modifying the mix ratios, in accordance with Abram's Law [42-44], it is possible to achieve much higher strengths, i.e. at least C50/60 classification based on initial findings.

The findings clearly show that wastewater sludge can potentially be used in concrete to mitigate on the environmental nuisance that results from the disposal of the liquid waste. Furthermore, this can also lead to a reduction in water demand which needs to be consumed wisely due to the repercussions of climate change across the globe. Evidently, further research is required, however, initial findings clearly show there is a future use for the utilisation of wastewater sludge in concrete.

\section{Conclusion}

This study investigated the suitability of WWS as a potential water replacement in concrete, with a focus on brewery digestate. Physiochemical analyses showed brewery WWS digestate exhibits very high moisture content ( $90 \% \mathrm{w} . / \mathrm{w}$.), therefore holding a great potential for hydration of cement. This application would increase the sustainability of concrete's life cycle, as the carbon content in the digestate's substitute can be trapped in the cement and help reduce its overall embodied $\mathrm{CO}_{2}$. The study also revealed that for low grade WWS digestate (low methane production rate), concrete applications should be preferred to further bioenergy generation. Land spreading would not be recommendable for this type of effluent, as it is known to contain organic pollutants that would accumulate higher up in the food chain. Depending on specific breweries products composition and toxic compound concentrations, the use of brewery WWS as soil fertilizer should be assessed on a case-by-case basis. Coherent and workable mixes were achieved with all levels of WWS content. The compressive strengths showed good repeatability, with strengths capable of structural applications being observed at 28 days, with all mixes exhibiting impressive early age strengths at 7 days of over $30 \mathrm{MPa}$. These results show that WWS can be used as a potential water replacement, thereby enhancing the sustainability of concrete. 


\section{Acknowledgement}

The authors would like to thank Kev Smith and Andy Brannan, Leeds Beckett University, for their assistance with the project.

\section{References}

1. Ahmed A, Kamau J, Pone J, Hyndman F, Fitriani H (2019) Chemical reactions in pozzolanic concrete. Modern Approaches on Material Science 1(4): 128-133.

2. Bapat J (2012) Mineral admixtures in cement and concrete, (1 $1^{\text {st }}$ edn), CRC Press, USA.

3. Mohammed 0, Hamid R, Taha M (2012) A review of sustainable supplementary cementitious materials as an alternative to all-portland cement mortar and concrete. Australian Journal of Basic \& Applied Sciences 6(9): 287-303.

4. Brien E, Dixon A, Sheils E (2012) Reinforced and prestressed concrete design to EC2. The Complete Process ( $2^{\text {nd }}$ edn), Spon Press, UK.

5. Akinboboye F, Ogunfayo I, Dawodu H (2012) Assessment of the severity of $\mathrm{CO}_{2}$ emission from anthill soils used as replacement for shale in cement manufacture.

6. Cline W (1992) The Economics of Global Warming. Peterson Institute, Washington, USA.

7. Yerramala A, Desai B, Rama chandurdu C (2012) Influence of fly ash replacement on strength properties of cement mortar. International Journal of Engineering Science and Technology 4(8): 3657-3665.

8. Soyka J, Conneely D, Michael J (1997) $\mathrm{CO}_{2}$ emissions from cement production. Good Practice Guidance and Uncertainty Management in National Greenhouse Gas Inventories, pp. 175-182.

9. Lippiatt B, Ahmad S (2004) Measuring the life-cycle environmental and economic performance of concrete: The BEES approach. Proceedings of the International Workshop on Sustainable Development and Concrete Technology, pp. 213-230.

10.Qadir M, Drechsel P, Jiménez Cisneros B, Kim Y (2020) Global and regional potential of wastewater as a water, nutrient and energy source. Natural Resources Forum 44(1): 40-51.

11.Perry M, De Villiers G (2003) Modelling the consumption of water and other utilities. Brauwelt International 5(3): 286-291.

12. Dos Santos, De Mello, Sérvulo F (2014) Solid wastes in brewing process: A review. Journal of Brewing and Distilling 5(1): 1-9.

13. Donoghue C, Jackson G, Koop J, Heuven A (2012) The environmental performance of the European brewing sector. European Union, pp. 1-43.

14.Sogn T, Dragicevic I, Linjordet R, Krogstad T, Eijsink G, et al. (2018) Recycling of biogas digestates in plant production: NPK fertilizer value and risk of leaching. International Journal of Recycling of Organic Waste in Agriculture 7(1): 49-58.

15. Digestate A, End of waste criteria for the production and use of quality outputs from anaerobic digestion of source-segregated biodegradable waste. Waste and Resources Action Programme (WRAP): Banbury, UK.

16. Møller J, Boldrin A, Christensen T (2009) Anaerobic digestion and digestate use: accounting of greenhouse gases and global warming contribution. Waste Manag Res 27(8): 813-824.

17. Alburquerque J, De la Fuente C, Ferrer-Costa A, Carrasco L, Cegarra (2012) Assessment of the fertiliser potential of digestates from farm and agroindustrial residues. Biomass and Bioenergy 40: 181-189.

18. Hospido A, Carballa M, Moreira M, Omil F, Lema J (2010) Environmental assessment of anaerobically digested sludge reuse in agriculture: potential impacts of emerging micropollutants. Water Res 44(10): 32253233.
19. Sluiter A, Hames B, Ruiz R, Scarlata C (1994) Determination of ash in biomass. Laboratory Analytical Procedure, National Renewable Energy Laboratory, Midwest Research Institute for the Department of Energy, USA.

20. Verein Deutscher (2006) VDI 4630 fermentation of organic materials. Characterization of the substrate, sampling, collection of material data, fermentation tests. p. 92.

21. BSI, BS EN 197-1 (2000) Part 1 Cement composition, specifications, and conformity criteria for common cements. British Standards Institution (BSI), London, UK.

22. BSI, BS EN 12390-1 (2012) Testing hardened concrete. Part 1: Shape, dimensions and other requirements for specimens and moulds. British Standards Institution (BSI), London, UK.

23. BSI, BS EN 12390-2 (2009) Making and curing specimens for strength tests. British Standards Institution (BSI), London, UK.

24. Oluokun F (1994) Fly ash concrete mix design and the water-cement ratio law. Materials Journal 91(4): 362-371.

25. Yerramala A, Desai B (2012) Influence of fly ash replacement on strength properties of cement mortar. International Journal of Engineering Science and Technology 4(8): 3657-3665.

26. BSI, BS EN 12390-4 (2000) Testing hardened concrete. Compressive strength. Specification for testing machines. British Standards Institution (BSI), London, UK.

27. Kamau J, Ahmed A, Hirst P, Kangwa J (2016) Suitability of corncob ash as a supplementary cementitious material. International Journal of Materials Science \& Engineering 4(4): 215-228.

28. Chen Y, Cheng J, Creamer K (2008) Inhibition of anaerobic digestion process: A review. Bioresource Technology 99(10): 4044-4064.

29. Krzemińska I, Oleszek M, Wiącek D (2019) Liquid anaerobic digestate as a source of nutrients for lipid and fatty acid accumulation by auxenochlorella protothecoides. Molecules 24(19): 3582.

30. Buswell A, Boruff C (1932) The relation between the chemical composition of organic matter and the quality and quantity of gas produced during sludge digestion. Sewage Works Journal 4(3): 454-460.

31. Tedesco S, Hurst G, Imtiaz A, Ratova M, Tosheva L, et al. (2020) $\mathrm{TiO}_{2}$ supported natural zeolites as biogas enhancers through photocatalytic pre-treatment of Miscanthus x giganteous crops. Energy 205: 117954.

32. Betlem K, Kaur A, Hudson A, Crapnell R, Hurst G, et al. (2019) ACS Applied Biomaterials 2(9): 3706-4105.

33. Risberg K, Cederlund H, Pell M, Arthurson V, Schnürer A (2017) Comparative characterization of digestate versus pig slurry and cow manure-chemical composition and effects on soil microbial activity. Waste Management 61: 529-538.

34. Amenorfenyo D, Huang X, Zhang Y, Zeng Q Zhang N et al. (2019) Microalgae brewery wastewater treatment: Potentials, benefits, and the challenges. Int J Environ Res Public Health 16(11): 1910.

35. Chiew Y, Spångberg J, Baky A, Hansson P, Jönsson H (2015) Environmental impact of recycling digested food waste as a fertilizer in agriculture-A case study. Resources, Conservation and Recycling 95: 1-14.

36. Hurst G, Brangeli I, Peeters M, Tedesco S (2019) Solid residue and by-product yields from acid-catalysed conversion of poplar wood to levulinic acid. Chemical Papers, pp.1-15.

37. Tattersall GH (1976) A viewpoint Publication. The workability of concrete.

38. https://www.aboutcivil.org/Properties-of-concrete-factors-affectingthem.html 
39. https://theconstructor.org/concrete/workability-of-concrete-typesstrength/11739/

40. BSI, BS EN 1992-1-1 (2004) Eurocode 2: Design of Concrete Structures, Part 1-1: General Rules and Rules for Buildings. British Standards Institution (BSI), London, UK.

41. BSI, BS 8500-1 (2015) Concrete-complementary British standard to BS EN 206. Part 1: Method of specifying and guidance for the specifier. British Standards Institution (BSI), London, UK.
42. Kamau J, Ahmed A, Hirst P, Kangwa J (2017) Performance of class $f$ pulverised fuel ash and ground granulated blast furnace slag in ternary concrete mixes. European Journal of Engineering Research and Science 2(6): 36-41.

43. Kamau J, Ahmed A, Hirst P, Kangwa J (2016) Viability of using corncob ash as a pozzolan in concrete. International Journal of Science, Environment and Technology 5(6): 4532-4544.

44. Oluokun F (1994) Fly ash concrete mix design and the water-cement ratio law. Materials Journal 91: 362-371. 